\title{
Erratum to: Efficacy and Safety of 5-Fluorouracil $0.5 \%$ /Salicylic Acid 10\% in the Field-Directed Treatment of Actinic Keratosis: A Phase III, Randomized, Double-Blind, Vehicle-Controlled Trial
}

Eggert Stockfleth - Ralph von Kiedrowski - Rolf Dominicus •

John Ryan · Adam Ellery · Meritxell Falqués · Nathalie Ivanoff ·

Rosario Rodriguez Azeredo

Published online: April 18, 2017

(C) The Author(s) 2017. This article is an open access publication

Erratum to: Dermatol Ther (Heidelb) (2017)

7:81-96

DOI $10.1007 / \mathrm{s} 13555-016-0161-2$

The authors would like to publish an erratum to correct the mistakes in Fig. 4 legend and in the text under the heading "Study Assessments and Endpoints" in the published article. The correct texts are given below.

1. Under the Fig. 4 legend the text currently reads: "a Partial clearance defined as $\leq 75 \%$ reduction in the number of clinically visible

The online version of the original article can be found under doi:10.1007/s13555-016-0161-2.

E. Stockfleth $(\bowtie)$

Department of Dermatology, Ruhr-University, Bochum, Germany

e-mail: e.stockfleth@klinikum-bochum.de

R. von Kiedrowski

Dermatological Practice, Selters, Germany

R. Dominicus

Proderma, Dülmen, Germany

J. Ryan

The Alverton Practice, Penzance, UK

A. Ellery

Cape Cornwall Surgery, Penzance, UK

M. Falqués · N. Ivanoff - R. R. Azeredo

Almirall S.A., Barcelona, Spain
AK lesions. 5-FU/SA 5-fluorouracil 0.5\%/ salicylic acid 10\%, AK actinic keratosis".

The figure " $\leq 75 \%$ " should be " $\geq 75 \%$ ".

2. The first paragraph of "Study Assessments and Endpoints" has repeated text. The text "and proportional change from baseline in the total number of lesions at each treatment visit and 8 weeks after the end of treatment." should be removed.

Open Access. This article is distributed under the terms of the Creative Commons Attribution-NonCommercial 4.0 International License (http://creativecommons.org/licenses/ by-nc/4.0/), which permits any noncommercial use, distribution, and reproduction in any medium, provided you give appropriate credit to the original author(s) and the source, provide a link to the Creative Commons license, and indicate if changes were made. 